\title{
A TURN TO LITURGY IN CONTEMPORARY POLITICAL THEOLOGY
}

\author{
Willy Gaut
}

\author{
| Research Group of \\ Fundamental Theology and Political Theology \\ Katholieke Universiteit Leuven \\ Leuven, Belgium
}

\begin{abstract}
:
Contemporary development of Christian political theology has been marked, among others, by a turn to liturgy. At first glance, such a turn might be easily associated with the sound principle of the inextricable connection between vita activa and vita contemplativa. The turn to liturgy, therefore, aims to affirm that mystics (the life of prayer) and politics (social engagement) should go hand in hand. However, does this classical idea stand as the sole reason for the turn to liturgy in the contemporary discussion in political theology? In this article, the author argues that while this classical argument still provides part of the answer to that question, the turn to liturgy in contemporary political theology to a considerable extent deals with the question of self-definition of the Church in exercising its political engagement. The turn to liturgy insists that the Church is inherently political, and thus its political significance is not defined by its relationship with the politics of the state alone. On the contrary, the political nature of the Church and its political role wells up from its identity as the sign and instrument of the Kingdom of God. As such, in its political engagement, the Church ought not to be considered merely as a social or voluntary organization.
\end{abstract}

Keywords:

political theology - liturgy - the Church - postliberal political theology • Kingdom of God • Christian ethics 


\section{Introduction}

A turn to liturgy has marked a significant part of the discussion in contemporary Christian political theology. There is even a notion that liturgy is a genuine political act of the Church. Such a growing stream raises a question about the significance of the relationship between politics and liturgy. What are the underlying theological rationales for this apparently novel development? One might argue that such a turn to liturgy intends to reaffirm the inextricable connection between vita activa and vita contemplativa, or mystics (the life of prayer) and politics (social engagement), as two sides of the same coin of Christian praxis. While this claim still holds true, does it stand as the sole reason for the turn to liturgy? Or, does the turn to liturgy have something to do with the more essential issue of self-definition of the Church in exercising its political engagement? By exploring the literature on contemporary political theology, this article aims to examine several key issues at stake in the turn to liturgy in the recent development of the field. To address this objective, this article will be divided into two major sections. The first section provides an overview of political theology, which includes two parts, namely the concept of political theology as well as its historical roots and the significance of political theology. The second section will focus on some key issues in the turn to liturgy in contemporary political theology.

\section{Political Theology: A General Overview}

\section{The Concept of Political Theology and Its Historical Roots}

The term 'political theology' has been used in a wide variety of ways. Although in the proceeding sections I will engage with many other authors, as a starting point I will appeal to the definition of political theology according to Peter Scott and William T. Cavanaugh. Their definition seems to be more comprehensive since they start by identifying the meaning of theology and politics separately. These authors put the definition of political theology this way:

"Theology is broadly understood as discourse about God, and human persons as they relate to God. The political is broadly understood as the use of structural power to organize a society or community of people. [...] Political theology is, then, the analysis and criticism of political arrangements (including cultural- 
psychological, social and economic aspects) from the perspective of differing interpretations of God's ways with the world."1

The definition above makes it clear that political theology refers to the discourse on the relationship between God and the faithful on the one hand and the political realm or political arrangement on the other. At the root of this analytical and critical discourse, there is a principle that people's faith in God is not merely a private matter. Conversely, it has something to do with the broader society. In addition, Scott's and Cavanaugh's definition clearly shows that the so-called political arrangement is a kind of general term which in fact includes many aspects of social life. What the people of faith deem as the way in which God relates to the world can be used as a point of view to analyze and critically evaluate the political arrangements of society. As Haak Joon Lee points it out, "political theology pursues the radical interruption and transformation of society in the eschatological anticipation of God's future." " Behind this idea, there is a conviction that the Church must become a "social-critical institution" and theology should be a liberating account of faith and hope. ${ }^{3}$

While being prevalent in other religious communities, it is nonetheless acknowledged that political theology has a specific Christian nuance. As Scott and Cavanaugh note, "the term 'political theology' was coined in a Christian context and has continued to be a significant term primarily within Christian discourse." ${ }^{\prime 4}$ This, of course, does not overlook the truth that political theology as such - although with a very distinct meaning - emerged for the first time not in the Christian context but in stoic philosophy in Ancient Rome. In this Stoic philosophy, the term political theology was used to point to the theology about the officially worshipped gods of the polis. In general, there were three types of god and therefore three types of theology: a) The personified force of nature which is related to natural theology; b) The gods of legend which is reflected in mythical theology; and c) The officially worshipped gods of the polis which is discussed in political theology. ${ }^{5}$

In the context of Christianity, according to Elizabeth Phillips, the explanation about how and when political theology came into existence refers to three important phases. ${ }^{6}$ The first phase points to the Jewish and Christian scriptures as the outset of the political theology. As Michael 
Kirwan remarks, the bible inspires the faithful and encourages them to work for a transformed world. Yet, as he maintains, the bible "leaves no blueprint or manifesto for this transformation" and only offers "lots of options (some more feasible than others) about what kind of society Christian should be struggling for, and by what means." "7 The second one is the first post-biblical work on political theology. Augustine's City of God is considered as the main reference in this stage. The third one refers to the development of political theology in the late twentieth century when political theology counted as a distinct academic discipline. In this regard, chief credit goes to Carl Schmitt, a German legal and political theorist, who introduced the phrase 'political theology'. Schmitt coined this term to speak of how the political concept in the modern state was formed. He granted that "all significant concepts of the modern theory of state are secularized theological concepts."

As for the emergence of political theology in the twentieth century, Phillips outlines three main factors at play. ${ }^{9}$ The first is related to the criticism coming from scholars of a wide range of disciplines (sociology, politics, philosophy, theology) about the theory of secularization. By the mid-twentieth century (circa the 1960s), the thesis of secularization about the decrease of membership in religion and its public role started to be put into question. It is argued, as Phillips observes, that "the removal of Christianity as a central feature of Western society was neither inevitable nor necessarily desirable." ${ }^{10}$ This new analysis suggests that instead of secularization and marginalization of religion, there exists a constant insistence for religions to exist in, and to contribute something for, public life.

Second, there was a need among the Christian Churches in the West to re-evaluate the relationship between the Church and the modern world. Such an attempt took its official form in such historical events as the Second Vatican Council of the Roman Catholic Church (1962-1965), the World Council of Churches Conference on Church and Society in Geneva (1966) and the World Council of Churches Fourth Assembly in Uppsala (1968). ${ }^{11}$ The Second Vatican Council, to mention but one example, adopted a more positive approach toward the world in place of the old one that was marked by a view of the material world as wholly evil. ${ }^{12}$ Third, there existed an increasing awareness of the danger of privatization

\section{5}


and spiritualization of Christian faith. Christian theologians started to question the presence of the Church in the face of atrocities like the Holocaust (in Germany), poverty (in Latin America) and racism, sexism as well as the marginalization of Christian convictions in public life (in North America). ${ }^{13}$ This has led to a growing awareness that religion should actively engage in any effort for liberation and social transformation.

The account of three factors contributing to its emergence in the twentieth century indicates that political theology does not refer to a single movement. ${ }^{14}$ One could say that political theology in fact appears as an umbrella term covering many different strands and that there is no single political theology. ${ }^{15}$ Of particular importance in this regard is the observation of Scott and Cavanaugh. They point out four factors that make for the extensive meaning and the various real forms of political theology: 1) The use of social sciences and other secular discourses; 2) The particular context in which political theology is done; 3) The extent to which the state is seen as the locus of politics; and 4) The way of using theological resources such as scriptures, liturgy and doctrine. ${ }^{16}$ In short, there are various ways of understanding and in turn of doing political theology.

\section{The Significance of Political Theology}

As is evident from its definition, as noted earlier, political theology tests the relationship between faith and politics. It reflects on the political engagement of the Church as the community of the people of faith. Such a political engagement derives from the conviction that Christian faith is not a private matter. ${ }^{17}$ On the contrary, it always has socio-political implications that demand it to contribute to the life of the larger society and does not confine itself within the boundaries of a religious community. Political theology reminds Christians that faith is not solely a vertical relationship with God but also a horizontal relationship with others. ${ }^{18}$ As leading political theologian Johann Baptist Metz remarks, political theology is "a critical correction of the privatization of modern religion and modern theology as transcendental, existential and personalistic." 19

Besides Caesaropapism, privatization of faith is another extreme model concerning the Church's relationship with public life. Privatization of faith 
is closely tied to the so-called classical secularization theory which holds that secularization is signified by the declination of the social significance of religion. ${ }^{20}$ Secularization relegates Christian faith to a private affair without any social relevance for public life. As explained earlier, the modern Christian political theology appears as the counterargument to such a notion of secularization. While admitting that the Church and the state remain autonomous domains, the two can still relate to one another. Political theology then deals with the attempt to articulate the political role that the Church should play.

Political theology, therefore, reflects on the political engagement of the Christians. Through this political engagement, according to Jürgen Moltmann, the faithful "participate in the public affairs of their societies and the world because they hope for the Kingdom of God and anticipate the justice and peace of the new earth as much as they can." 21 Recognizing Moltmann's view, one may conclude that political dimension is not an additional aspect of faith which should be taken into account only if we want to make Christian faith relevant for the world. Christian faith is inherently political. As Moltmann expounds, the political nature of the Church stems from the hope for the Kingdom of God that is central to Christian faith. Thus, the political engagement of the Church in the world lies at the heart of Christian faith.

Reflecting on the social dimension of Christian faith and the political engagement of the Church, Cavanaugh and Scott argue that political theology therefore has a threefold task. ${ }^{22}$ First, political theology links Christian faith and political realm while maintaining the proper autonomy of each. Politics deals with public authority, while theology is one to do with faith. The two, however, can engage in a critical encounter. Second, political theology examines the ways in which theological discourse reproduces inequalities of class, gender or race and to reconstruct theology so that it serves to contribute to justice. Kirwan is therefore right to say that political theology in some respect serves the same way as the critique of religion voiced by thinkers like Ludwig Feuerbach and Karl Marx who viewed religion as legitimizing alienation and injustice as well as serving as opium for the oppressed. ${ }^{23}$ Third, political theology also discloses the false theologies underlying the supposedly secular politics and promotes the politics implicit in a theology. 
The account of the threefold task of political theology above evidently suggests that political theology not only deals with the role of the Church as "a social-critical institution" and the insistence on theology to be a liberating account of hope and faith as Metz has argued, ${ }^{24}$ but in addition it has something to do with the Church and theology as such. In the reflections of political theologies, the relationship between the Church and theology on the one hand and the political institutions and public affairs on the other is a reciprocal one. The interplay between the Church and the political institutions serves not only as an opportunity for the Church to present itself as a social-critical institution toward the political one but also a chance for doing self-criticism as the second and the third tasks of political theology seem to highlight.

\section{Whose Politics? A Preliminary Conclusion}

Whatever the strand, the field of political theology is reflected in its emphasis on the socio-political dimension of Christian faith. First, political theologies remind the Church of the social-political dimension and the liberating aspect of the Christian faith. Lisa Sowle Cahill puts it eloquently as she remarks that "for the political theologians, to be a Christian is to be committed to the Gospel in the world and to the reordering of the world in light of the radical message of the Gospel." ${ }^{25}$ However, second, it is worth noting that the Church and the state still remain two separate domains. Political theology accepts neither privatization of Christian faith nor Caesaropapism. In the face of political power and institutions of the state, the Church presents itself as an institution of social criticism, a social force bearing the task of encouraging the social transformation of society. Third, in undertaking its political engagement, the Church should point to the values of the Gospel and the Kingdom of God as its reference. ${ }^{26}$

Nevertheless, even if the account of the nature of political theology is granted, one crucial question remains: Whose politics is the Church engaged in? Although in playing its role as an institution of social criticism the Church may refer to the values of the Gospel and the Kingdom of God, in fact the Church simply serves the politics of the state. Consequently, the political nature of the Church is defined by its relationship with the state. 
In this regard, Stephan van Erp's observation is of decisive importance. He notes that in many political theologies, the political nature of the Church is understood more in relation to its role "as a political instrument for social change" rather than "as a sign and instrument of God's political ordering of the world toward his Kingdom." ${ }^{27}$

Such an observation serves well to lay the foundation for effort to articulate anew the political nature of the Church that does justice to the idea of the Church as a sign and instrument of the Kingdom of God. In this new articulated way, the political nature of the Church is no longer solely defined by its relationship with the state, since the political engagement of the Church is first and foremost for the sake the Kingdom of God, and not for the sake of the state alone. In its contemporary development, political theology becomes all the more aware of this issue and tries to reformulate the political nature of the Church as a sign and instrument of the Kingdom of God and its political engagement with the world. As we will see, a turn to liturgy in contemporary political theology is part of this movement.

\section{The Turn to Liturgy in Contemporary Political Theology: Key Issues and Chief Arguments}

\section{Understanding Liturgy}

The term 'liturgy' in the discourse of the turn to liturgy in contemporary political theology refers to the worship of the Church. Before going further to explore the major reasons for the turn to liturgy in contemporary political theology, it is useful to add a caveat of the essence of liturgy. In his book entitled Liturgy and Secularism: Beyond the Divide, Joris Geldhof proposes a new direction of understanding liturgy. Instead of an epistemological approach dealing with the question of what liturgy is, he prefers a topographical and chronological approach centered around the questions of where the liturgy is and when the liturgy is. His elucidation on these topographical and chronological approaches merits quoting at length:

"Where is the liturgy? The liturgy is everywhere the mystery of redemption is actualized, enacted, offered, performed, transmitted, implemented. It is wherever assemblies gather to praise the Lord in communion with the angels 
and the saints and in accordance with the apostolic witness. When is the liturgy? The liturgy is anytime the Church is doing what she is supposed to do, that is, when she works through her 'agenda' and when she listens to and speaks the Word of God. The liturgy is when the body of Christ is sacramentally seen and ecclesially realized, and when the people of God actually become what they are supposed to be: 'a chosen race, a royal priesthood, a holy nation, God's own people’ (1 Pet 2:9)."28

Such an explanation adequately expresses what is central to liturgy, namely God's salvific work for the world. Through their worship, the faithful celebrate God's salvific work sacramentally and at the same time express their response to such an abundant grace of salvation. Accordingly, liturgy has both katabatic and anabatic dimensions. ${ }^{29}$ Liturgy actualizes not only the flow of grace from God to the world but also what human beings and the world are supposed to do in response to that grace. David Fagerberg correctly affirms that liturgy has two ends, namely "the sanctification of human beings and the glorification of God." ${ }^{30}$ Whenever and wherever the faithful gather together for the celebration of liturgy, it is those two elements of the mystery of salvation that they celebrate.

In what follows, I will examine some major issues in the turn to liturgy in contemporary political theology. The first issue, namely a plea for rearticulating the political nature of the Church, is the main context from which the liturgical turn in contemporary political theology has emerged. In this part, I will discuss the emergence of postliberal political theology and the plea for rearticulating the political nature of the Church. The second issue is related to the ethical-political dimension of Christian liturgy. In this section, I will elucidate the role of liturgy for the Church's political engagement as a sign and instrument of the Kingdom of God. The role of liturgy as the wellspring of Christian ethics and its contribution to the formation of political agents will be the major concerns of this section.

\section{Liturgy as the Primary Political Act of the Church: Postliberal Political Theology}

\section{The Emergence of Postliberal Political Theology}

The turn to liturgy in contemporary political theology is first and foremost related to the reaction to what Wannenwetsch identifies as the "modern tendency", namely "the tendency to identify the political meaning of the Church primarily or exclusively in respect of its relationship to the 
state or the influence it seeks to bring to bear on civil society." "' To put it another way, the Church is political in so far as it is related to the state and civil society. Within this model of understanding, political engagement means to intervene in the state's affair. This position clearly assumes that politics is the state's affairs only. The far-reaching consequence of this stance is manifested in the conviction that the Church is political so long as it is related to the state.

Such a modern tendency has characterized what Bell calls the "dominant forms of political theology", given that it has been the main feature in this field since the decade of the 1960s. ${ }^{32}$ According to Bell, this dominant model of political theology was heavily influenced by liberalism which holds that "politics remains a matter of statecraft". ${ }^{33}$ This dominant model accepts the vision of modernity - among others, emancipation from tradition, the advance of secularization, the Enlightenment, the rise of the nation-state - while being critical of its failures. It is within this context that the Church is called "to function as a permanent critique of any and every social order in the name of a more just future." 34 The Church fulfils that function by being a moral instance for the state, promoting values in order to encourage the state to keep faithful on its own track. The task of the Church is to nurture the vision of the modern state. ${ }^{35}$ This dominant model, Bell emphasizes, strives to "complete the promise of modernity and its liberal politics." 36

The idea of the political engagement of the Church as a matter of intervention to the politics of the state can be explained on the basis of the basic concept of politics, as addressed by James K. A. Smith, one of the leading figures in the turn to liturgy in contemporary political theology. In his book entitled Awaiting the King: Reforming Public Theology, Smith argues that the major problems in the existing paradigm of political theology are related to the way of understanding politics. For Smith, politics has been often defined in a spatial and rational way of thinking. As to the spatial way of thinking, Smith contends that people tend to think of politics as a real territory. In the meantime, the rational way of thinking is concerned with the way of understanding and treating the citizens as merely "rational actors". 37

The framework of spatialization and rationalization brings about two consequences. First, as people think of politics as a territory, the definition 
of politics is nothing other than the state. In this context, according to Smith, the main question in political theology is therefore "how to relate the spheres of the Church and that of the state." 38 This is precisely the case in the dominant model in political theology. Second, the political participation of citizens is simply reduced to a kind of proceduralism. The political act is reduced to a matter of expressing "conscious deliberation rooted in beliefs and ideas," and accordingly, the political is pictured as an arena in which the citizens express their "beliefs, legislate what they know, and codify laws to be disseminated." 39

The reaction to the aforementioned existing model has come from the so-called postliberal political theologians with the leading members such as Stanley Hauerwas, John Milbank, and Oliver O'Donovan. ${ }^{40}$ Postliberal political theology, as Bell affirms, "rejects politics as statecraft and envisions the Church as a concrete public, political space in its own right." 41 The proponents of the postliberal position are in favor of the notion of - to cite Wannenwetsch - "the political nature of the Church as politeia in its own right." 42 Carrying this notion a bit further, one may agree with George Kalantzis and Gregory W. Lee as they hold that "the primary locus of Christian political activity is the Church."43 In short, according to this position, the Church is inherently - or even independently - political.

Against the idea of Christianity as just a matter of values, worldviews or a basic philosophical orientation, the proponents of the postliberal political theology argue that the dominant model of political theology "reduces Christian political engagement to the option offered by the world, more specifically, by the regnant of liberal order." ${ }^{44}$ Rather than expressing itself as inherently political, the dominant tradition determines the political engagement of the Church as a matter of taking part in the politics of the state. The postliberal position, for example, advocates that Christian politics takes place in the Church itself. If politics is understood as organizing human community, the Church has its own politics without being merely a custodian of values or worldviews for the advancement of the state. ${ }^{45}$

Instead of just taking part in and serving the politics of the state, the political engagement of the Church according to the postliberal position is primarily a matter of exercising its own politics. Bell describes this position clearly when he writes: "Christian politics takes place in the 
distinct witness of the Church to Christ's redemption of politics as the renewal of the friendship/community of humanity in God." ${ }^{46}$ This being so, the politics of the Church should be defined in the framework of its role in God's plan of salvation for the world. Bell goes on to say, it is in the liturgy - especially the Eucharist - that Christ's reconciling sacrifice is celebrated. ${ }^{47}$ The Church, therefore, fulfils its public and political nature its role of renewing human community, in celebrating its liturgy. Liturgy is in fact the primary political act of the Church, according to this position.

\section{Rearticulating the Political Nature of the Church: The Primacy of Liturgy}

Contrary to the position of the dominant forms of political theologies, Smith proposes a more substantial way of thinking of politics. Going beyond the procedural one, Smith defines politics more as a way of life. This is evident as he claims that "the political is less space and more a way of life." ${ }^{\prime 8}$ Clearly, politics is neither reduced to the state nor is it simplified to be merely the procedures in the politics of the state. As such, instead of thinking of polis as a public square where people come with their beliefs and ideas and take part in political discourse, Smith considers polis as "a formative community of solidarity". ${ }^{49}$ In consequence, political participation is not a matter of sharing ideas or beliefs, but practicing certain habits for living in community.

In Smith's analysis, the emergence of the substantial way of thinking of politics as a way of life coincides with the shift in the emphasis on the meaning of religion in general and Christianity in particular. Religion is not merely about beliefs and worldviews, but also practice, that is ritual and worship. ${ }^{50}$ Vincent Lloyd writes in much the same term. He contends that religious authority resides primarily in religious practice and only secondarily in religious doctrine and religious people. ${ }^{51}$ What makes Christians distinct is not only their worldviews that are expressed in beliefs and doctrines alone, but also a certain practice that they consider to be important in their religious life. This certain practice is worship or liturgy. On this point, in Desiring the King: Worship, Worldview and Culture, Smith convincingly writes, "humans are those animals that are religious not because we are primarily believing animals but because we are liturgical animals." 52

What Smith notes here finds its resonance in the work of Catherine Pickstock. In her article entitled "Liturgy, Art, and Politics," Pickstock 
observes that at its primary condition, human beings are liturgical. So, she writes, "all cultures begin in liturgy which fuses the repetition of ideal values, with physical inscription upon bodies, places, times and motions." 53 The notion of human beings as homo liturgicus is part of the critique of the modern view that focused on the rational aspect of human beings to the detriment of other aspects. The rational point of view sees human beings as "fundamentally thinking thing". ${ }^{44}$ Human beings are defined by their rational capacity which takes the concrete form in the activity of thinking. By contrast, the postmodern view - as one might call it - takes other aspects into account in order to promote a more integral approach in defining the existence of human beings. From this postmodern standpoint, as Smith claims, "human persons are not primarily or for the most part thinkers, or even believers," but rather they "are - fundamentally and primordially - lovers." 55

The idea about the primacy of religious practices in defining Christianity influences the new way of understanding the political nature of the Church and of articulating its political engagement. As observed earlier, the more substantial way of thinking of politics goes beyond the spatial and the rational ones. When politics is perceived in a spatial and rational way of understanding, the political engagement of the Church is impoverished as simply a matter of participation as an institution of social criticism in the politics of the state. In this model, the locus of the Christian political activity is no longer primarily in but outside the Church, namely in the public sphere. ${ }^{56}$ The Church becomes political only by its participation in civil society along with many other social organizations. The far-reaching consequence of this model is that the Church acts as an interest group or - as Stanley Hauerwas points out - "a voluntary association" which "assumes their religious convictions should be submitted to a public order governed by secular rationality." 57 In doing so, instead of exercising its own politics, the Church is actually taking part in the politics of the state. As a result, as van Erp notes, the Church ends up being "merely a political organization". 58

Unlike the spatial and rational ways of understanding politics, the substantial one which defines politics as a way of life asserts that the primary locus of the Church's political activity is within the Church itself. ${ }^{59}$ The political nature of the Church is not merely a matter of developing a relationship with the state or civil society, but more about forming the 
way of life. This, of course, applies also to the political engagement of the Church. As Smith describes it:

"Our political theologies need to worry less about policing boundaries and securing a platform for expressing our beliefs and instead carefully consider the ways that political life is bound up with the formation of habits and desires that make us who we are."

What sort of political engagement of the Church matches the idea of politics as a way of life? If politics is more about a way of life, and no longer merely about space of expressing ideas, the political engagement of the Church then aims at forming certain habits or ways of life. In this regard, Smith argues that the Church is supposed to take part in the attempt "to shape the ethos of a nation, a state, a municipality to foster a way of life that bends toward shalom." ${ }^{\prime 11}$ In so doing, the state and the governmental institutions are not the only targets of the Church's political act. Accordingly, the political engagement of the Church is no longer confined to performing the critical function over the state or the government. Instead, it should address "the polis that is 'the society". ${ }^{62}$

In sum, the Church is doing its political engagement not as it is participating in the procedural act to intervene in the politics of the state, but rather when it is taking part in instilling the values that mark the identity of the social human nature through the formation of a certain way of life. ${ }^{63}$ Politics has something to do with the formation of the virtuous human beings capable of living in the common life of the society. According to Smith, "If politics is habit forming, it is also love shaping, which means that we are on the terrain of liturgy." ${ }^{64}$ How does liturgy play a role in habit forming? With this inquiry in mind, I now turn to an examination of the ethical-political dimension of Christian worship.

\section{The Ethical-Political Dimension of Christian Liturgy}

\section{Liturgy as the Wellspring of Christian Ethics}

The notion of liturgy as the source of ethics is yet another crucial consideration for the significance of liturgy for the Church's political engagement. The underlying idea of this notion is that worship provides the ethical ground for the Church to engage with the world. For this reason, as Wannenwetsch argues, worship is considered as "the beginning 
of Christian ethics" and "the grammar that forms Christian life". ${ }^{65}$ Worship is called the grammar of Christian life because participation in worship is an opportunity for Christians to experience "the acting and the judging of God" which in turn "guide believers to a specific form of life" as they engage with the world. ${ }^{66}$ Such an awareness, after all, has drawn the attention of the scholars who develop the so-called "ecclesial ethics", namely ethics that derives from the Church's narrative and practice. ${ }^{67}$

The pivotal role of worship as the grammar of Christian life has at least three implications for the Christians' political engagement. First, Christians must be aware of themselves as the people of God, "a community living in accord with the law of the Spirit of Christ." 68 Such awareness is constituted in worship. Wannenwetsch claims that "the worshipping community is the true public, namely public of the Spirit." Political nature of the Church and its public character must be primarily understood in this framework of thought. ${ }^{70}$ While political engagement in the world is of paramount importance, it must be seen as something rooted in citizenship in God's Kingdom. That is to say, the centrality of liturgy reminds every Christian that while they are active in the world, they are primarily the citizens of the Kingdom of God.

Second, the notion of worship as the grammar of Christian life in some respects blurs the dichotomy that has been made between "public and private" or "vita activa and vita contemplativa". ${ }^{71}$ Christian worship is something particular for Christians themselves. Yet, it somehow carries public and political implications. Speaking of the role of liturgy for the formation of Christian agents, Graham Ward points out that Christians are conformed to Christ through certain practices which at the same time "govern their relations to the world". ${ }^{72}$ Since the ethical formation performed in liturgy is a preparation for the Church to engage with the world, one could say that worship is already part of the Church's political activity. As Smith forcefully remarks, "the politics of worship is tied to the renewal of moral agency of the people of God, who are formed to be sent." 73

Third, a political engagement which springs from worship is a critical and transformative one. Since worship provides Christians with the opportunity to be instilled by God's vision and act, Christians are sent to perform their political engagement in a way that reflects those vision and act. Christian political act then should be a "participation in the 
operations of God in the world". ${ }^{74}$ Worship has the power to transform the perception, vision and action of the Christians who are in turn sent to the world. In this way, the political engagement of Christians can mean putting vis-à-vis God's politics and worldly politics. Through their political engagement, Christians offer a different kind of politics based on God's vision and act. In the words of Wannenwetsch, worship serves as an "interruption of daily political happening". 75

\section{Liturgy and the Formation of Political Agents}

In so far as understood as a way of life, politics has something to do with regular or routine practice. Regularity of practice is an essential characteristic of liturgy. With its regular character, liturgy plays a significant role in shaping the Christians' way of life. As politics is understood as the way of life, the Church's political engagement is performed first and foremost in its liturgy. It is said so because, as Smith argues, liturgy deals with habits forming as well as love shaping. ${ }^{76}$ In Smith's view, the role of liturgy in the formation of political agents is primarily related to its function in the formation of habits. A way of life is closely connected to practice. However, to become a way of life, a practice should be done regularly and repeatedly. This is the point of interconnection between practice and habit. ${ }^{77}$

Smith contends that our orientation in life is affected by our habits and disposition, while these habits and dispositions are formed through "affective, bodily means, especially bodily practices, routines, or rituals". ${ }^{78}$ Smith goes on to say that these routine bodily practices "grab hold of our hearts through our imagination, which is closely linked to our bodily sense." ${ }^{\prime 79}$ As a routine spiritual practice, Smith maintains, liturgy is capable of forming our character, shaping our identity and sharpening our vision of a good life, which are nothing other than the qualities we need in order to orient ourselves rightly to the world. ${ }^{80}$ Luke Bretherton puts the matter well as he holds that the way we encounter God in prayer in turn affects the way we relate to our neighbors. That is to say, the constant encounter with God in prayers brings about the new, transformed way in viewing and approaching others in daily life. ${ }^{81}$

How does the liturgy serve the identity formation of Christians and offer a vision of a good life? Liturgy plays an indispensable role in conjuring 
up the social imagination of Christians. Smith, for example, considers liturgy as the rituals and practices containing stories which can be the source of vision of a good life. He argues that liturgy consists of "storyladen practices that are absorbed into our imaginative epicenter of action and behavior." 82 Participating in liturgy therefore implies a willingness to absorb the stories embodied in those practices, appropriating the vision of life they bring about and performing good deeds they suggest. In this regard, Willimon and Hauerwas are right to insist that Christians should be aware that "our ethics is a byproduct of our worship". 83 The way we construct our identity and perform our act are determined by the vision of life that we share and the perception of life that we have. We receive such vision and perception from the stories we absorb. This also applies to Christian identity and acts alike which are determined by Christian stories.

Christian stories that are central to the formation of Christian identity and the vision of a good life are the ones about God's salvific action through Christ. ${ }^{84}$ Christian stories, to put it differently, are the stories of God's people, a community redeemed by God's salvific work. Christian identity is formed through the narration of "God's covenant with His people", the narrative which is reprised in worship. ${ }^{85}$ By repeatedly listening to these stories, they then become part of our imagination and therefore "govern our habitus", our real act and behavior which are nothing other than the representative of our vision of life in the world. ${ }^{86}$ Christian stories, in short, determine "the unique 'political' imaginary of the people of God." $" 87$

Social imaginary of the people of God relates them to three forms of time, namely the past, the present and the future. It is linked to the past in that it recounts the story of God's salvific act as documented in the biblical stories and celebrated in liturgy. These stories remind us of "a social imaginary that constitutes the biblical vision of flourishing for creation and culture." 88 In his analysis of the relationship of liturgy and ethics, Bruce Morrill notes that remembrance is of great importance in Christians' social and political engagement. For him, Christian faith is centered around "praxis of memory, narrative and solidarity engaged in the real history of suffering humanity", of which scripture and liturgy serve as it means. ${ }^{89}$ 
The Christian social imaginary is related to the present because we read the biblical stories about God's salvific work while holding the faith that the same God is still at work in this world. That is to say that we read the biblical stories with an awareness that the "public history of human socio-political life is an arena in which God also acts." ${ }^{\text {90 }}$ So, our political imagination shaped by biblical stories in turn helps us "read political history more broadly in order to discern how God's in-breaking into history has impacted and continues to impact our political experiments." ${ }^{91}$

As to the future, listening to the stories of God's salvific act encourages us to keep alive the hope that the politics of the world is paving the way to its fulfillment in God. The futuristic dimension of the Christian stories indicates that Christian social imaginary is indeed a condensation of hope for the coming of the Kingdom of God. In the part dealing with the relationship between liturgy and society in Holy Things: A Liturgical Theology, liturgical theologian Gordon Lathrop already developed this theme profoundly. In his view, by their participation in liturgy, Christians are called "to relativize all the conventions of the world and to cry out against the suffering they cause, waiting for the truth of God and beginning to act out now that justice for which we wait." ${ }^{\prime 2}$

Such Christian stories that shape the Christians' imagination, and in turn their identity, are told and performed in liturgy. Smith is therefore right to assert that the "shorthand term for such a narrative practice is worship". ${ }^{33}$ Since they are based on the Kingdom of God, not on the politics of the world, Christian stories are able to offer an alternative social imaginary. Bretherton makes an interesting observation in this regard. For him, prayer is inherently political precisely because "in prayer we discover alternative repertories or scripts for envisioning the world to those of the dominant hegemony." ${ }^{\prime 94}$ In other words, prayer has the capacity of being a counter politics for the existing political institutions because it is through prayer that one may be introduced to God's politics.

With this new vision of a life which is based on the imaginary of the Kingdom of God, Christians are sent into the world. This alternative social imagination should generate action. Christians are supposed to live in society with a new vision of life based on the values of the Kingdom of God. On this point, Smith argues that before God we are worshippers, 
before the world we are "actors, doers, engaged makers and muddlers in a material world that is our home, our environment, our milieu, our dwelling." ${ }^{95}$ Christian worship, therefore, has a transformative mission. Jennifer M. Bridge summarizes it forcefully when she says that "the worship that is pleasing to God must be tied to works of mercy and justice."96

\section{Conclusion}

This article has provided an overview of political theology and a contemporary trend in the field which is characterized by a turn to liturgy. While to a certain measure explaining the inextricable connection between vita activa and vita contemplativa, which is clear from the account of the ethical-political dimension of Christian liturgy, in large measure, the turn to liturgy in contemporary political theology speaks of the selfdefinition of the Church in exercising its political engagement. The turn to liturgy shows that the political nature of the Church is not defined by its relationship with the state alone. The political engagement of the Church, therefore, is not confined to the issue of participating in the politics of the state but rather a matter of performing its own politics as a sign and instrument of the Kingdom of God. In short, such political engagement is an opportunity for the Church to make manifest God's own politics.

Within this line of thought, I have argued in this contribution that the liturgy can serve as the primary political act of the Church. The primacy of liturgy, however, by no means leads to withdrawing the Church from its political engagement with the world. Unique to this liturgical turn is its emphasis that the Church is inherently political, and this political nature derives from the role it plays in God's salvific work for the world. However, while the key issues of the turn to liturgy in contemporary political theology might have been extensively discussed, it must be noted nonetheless that the present contribution only touches on the general idea of liturgy. Further research is needed to explore more deeply how the notion of liturgy as the political act of the Church par excellence is justified in certain liturgical practices. 


\section{Bibliography:}

Bell Jr., Daniel M. "Postliberalism and Radical Orthodoxy." In The Cambridge Companion to Christian Political Theology. Ed. Craig Hovey and Elizabeth Phillips, 110-132. Cambridge: Cambridge University Press, 2015.

. "State and Civil Society." In The Blackwell Companion to Political Theology. Ed. William T. Cavanaugh and Peter Scott, 423-438.

Malden, Oxford and Victoria: Blackwell Publishing, 2004.

Bretherton, Luke. Christianity and Contemporary Politics: The Condition and Possibilities of Faithful Witness. Oxford: Wiley Blackwell, 2010.

Cahill, Lisa Sowle. "Catholic Social Teaching." In The Cambridge Companion to Christian Political Theology. Ed. Craig Hovey and Elizabeth Phillips, 67-87. Cambridge: Cambridge University Press, 2015.

Cavanaugh, William T. Theopolitical Imagination: Discovering the Liturgy as a Political Act in an Age of Global Consumerism. London and New York: Bloomsbury, 2002.

Cavanaugh, William T. and Peter Scott. "Introduction." In The Blackwell Companion to Political Theology. Ed. William T. Cavanaugh and Peter Scott, 1-3. Malden, Oxford and Victoria: Blackwell Publishing, 2004. Fagerberg, David W. "Liturgy, Signs, and Sacraments." In The Oxford Handbook of Sacramental Theology. Ed. Hans Boersma and Matthew Levering, 455-465. Oxford: Oxford University Press, 2015.

Gaillardetz, Richard R. and Catherine E. Clifford. Keys to the Council: Unlocking the Teaching of Vatican II. Minnesota: Liturgical Press, 2012. Geldhof, Joris. Liturgy and Secularism: Beyond the Divide. Minnesota: Liturgical Press, 2018.

Hauerwas, Stanley. "Church Matters." In Christian Political Witness.

Ed. George Kalantzis and Gregory W. Lee, 17-34. Illinois: IVP Academic, 2014.

Kalantzis, George and Gregory W. Lee. "Introduction." In Christian Political Witness. Ed. George Kalantzis and Gregory W. Lee, 9-16. Illinois: IVP Academic, 2014.

Kirwan, Michael. Political Theology: A New Introduction. London: Darton, Longman and Todd, 2009. 
Lathrop, Gordon W. Holy Things: A Liturgical Theology. Minneapolis: Fortress Press, 1993.

Lee, Haak Joon. "Public Theology." In The Cambridge Companion to Christian Political Theology. Ed. Craig Hovey and Elizabeth Phillips, 44-65. Cambridge: Cambridge University Press, 2015.

Lloyd, Vincent. The Problem with Grace: Reconfiguring Political Theology. California: Stanford University Press, 2011.

McBride, Jennifer M. Radical Discipleship: A Liturgical Politics of the Gospel. Minneapolis: Fortress Press, 2017.

Merrigan, Terrence. "The Exile of the Religious Subject: A Newmanian Perspective on Religion in Contemporary Society." In A Catholic Minority Church in a World of Seekers. Ed. Staf Hallemans and Peter Jonkers, 193-222. Washington DC: The Council for Research in Values and Philosophy, 2015.

Metz, Johann Baptist. Theology of the World. Trans. William Glen-Doepel. New York: Herder and Herder, 1969.

"Two-fold Political Theology." In Political Theology:

Contemporary Challenges and Future Directions. Ed. Francis S. Fiorenza,

Klaus Tanner and Michael Welker. Kentucky: Westminster John Knox Press, 2013.

Moltmann, Jürgen. "European Political Theology." In The Cambridge Companion to Christian Political Theology. Ed. Craig Hovey and Elizabeth Phillips, 3-22. Cambridge: Cambridge University Press, 2015.

Morrill, Bruce T. Anamnesis as Dangerous Memory: Political Theology and Liturgical Theology in Dialogue. Minnesota: Liturgical Press, 2000. . "Time, Absence, and Otherness: Divine-Human Paradoxes

Boding Liturgy and Ethics." In Sacraments: Revelation of the Humanity of God - Engaging the Fundamental Theology of Louis-Marie Chauvet. Ed. Philippe Bordeyne and Bruce T. Morrill, 137-152. Minnesota: Liturgical Press, 2008.

Phillips, Elizabeth. Political Theology: A Guide for the Perplexed. London and New York: Bloomsbury, 2012.

Pickstock, Catherine. "Liturgy, Art, and Politics." Modern Theology 16 (2000): 159-180.

Smith, Carl. Political Theology: Four Chapters on the Concept of Sovereignty. Trans. George Schwab. Cambridge: MIT Press, 1985 [1934]. 
Smith, James K. A. Awaiting the King: Reforming Public Theology. Michigan: Baker Academic, 2017. . Desiring the Kingdom: Worship, Worldview and Cultural Formation. Michigan: Baker Academic, 2009. . Imagining the Kingdom: How Worship Works. Michigan: Baker Academic, 2013.

Van Erp, Stephan. "World and Sacrament: Foundations of the Political Theology of the Church." Louvain Studies 39 (2016): 102-120.

Vatican Council II. "Sacrosanctum Concilium, The Constitution on the Sacred Liturgy." In Decrees of the Ecumenical Councils: Trent to Vatican II. Ed. Norman P. Tanner, Vol. 2, 820-843. Washington DC: Sheed \& Ward and Georgetown University Press, 1990.

Wannenwetsch, Bernd. "Liturgy." In The Blackwell Companion to Political Theology. Ed. William T. Cavanaugh and Peter Scott, 76-90. Malden, Oxford and Victoria: Blackwell Publishing, 2004. Political Worship. Trans. Margaret Kohl. New York: Oxford University Press, 2004.

Ward, Graham. "A Christian Act: Politics and Liturgical Practices." In Liturgy, Time and Politics of Redemption. Ed. Randi Rashkover and C. C. Pecknold, 29-49. London: SCM Press, 2006.

Weigel, George. Soul of the World: Notes on the Future of Public Catholicism. Michigan: Ethics and Public Policy Center and William B. Eerdmans Publishing Company, 1996.

Wells, Samuel and Ben Quash. Introducing Christian Ethics. Oxford: Wiley Blackwell, 2010.

Willimon, William H. and Stanley Hauerwas. Lord, Teach Us: Lord's Prayer and the Christian Life. Nashville: Abingdon Press, 1996.

Yong, Amos. In the Days of Caesar: Pentecostalism and Political Theology. Michigan and Cambridge: William B. Eerdmans Publishing Company, 2010. 


\section{Endnotes:}

1 William T. Cavanaugh and Peter Scott, "Introduction," The Blackwell Companion to Political Theology, ed. William T. Cavanaugh and Peter Scott (Malden, Oxford and Victoria: Blackwell Publishing, 2004) 1.

2 Haak Joon Lee, "Public Theology," The Cambridge Companion to Christian Political Theology, ed. Craig Hovey and Elizabeth Phillips (Cambridge: Cambridge University Press, 2015) 54.

3 Johann Baptist Metz, Theology of the World, trans. William Glen-Doepel (New York: Herder and Herder, 1969) 96, 123.

4 Cavanaugh and Scott, op. cit., 1-2. Of course, what they mean is political theology as it is conceived now as a theological discipline which examines the relationship between the Church and the political institution, while the term political theology itself originally did not come from Christian theology.

5 Elizabeth Phillips, Political Theology: A Guide for the Perplexed (London and New York: Bloomsbury, 2012) 4.

$6 \quad$ Ibid., 11.

7 Michael Kirwan, Political Theology: A New Introduction (London: Darton, Longman and Todd, 2008) 3-4. On the contribution of the bible to political theology is discussed extensively in chapter 10 of this book.

8 Carl Schmitt, Political Theology: Four Chapters on the Concept of Sovereignty, trans. George Schwab (Cambridge: MIT Press, 1985 [1934]) 36.

9 Phillips, op. cit., 28.

10 Ibid., 28.

11 Ibid., 29.

12 Richard R. Gaillardetz and Catherine E. Clifford, Keys to the Council: Unlocking the Teaching of Vatican II (Minnesota: Liturgical Press, 2012) 87-94.

13 Phillips, op. cit., 29-30.

14 Amos Yong, In the Days of Caesar: Pentecostalism and Political Theology (Michigan and Cambridge: William B. Eerdmans Publishing Company, 2010) 82.

15 Phillips, op. cit., 31.

16 Cavanaugh and Scott, op. cit., 2.

17 Jürgen Moltmann, "European Political Theology," The Cambridge Companion to Christian Political Theology, ed. Craig Hovey and Elizabeth Phillips (Cambridge: Cambridge University Press, 2015) 3, 8.

18 Phillips, op. cit., 3. Phillips highlights here that political theology appears as a twofold critique: 1) As a critique of both atheists and secularists who consider that theology discredits politics; 2) As a critique of the Christians who contend that their faith is merely a matter of relationship with God and not with the temporal things.

19 Metz, op. cit., 116. Elsewhere Metz explains that he develops this idea as his reaction to Karl Rahner's transcendental-anthropological theology. Cf. Johann Baptist Metz, "Two-fold Political Theology," Political Theology: Contemporary Challenges and Future Directions, ed. Francis S. Fiorenza, Klaus Tanner and Michael Welker (Kentucky: Westminster John Knox Press, 2013) 14. 
20 Terrence Merrigan, "The Exile of the Religious Subject: A Newmanian Perspective on Religion in Contemporary Society," A Catholic Minority Church in a World of Seekers, ed. Staf Hallemans and Peter Jonkers (Washington DC: The Council for Research in Values and Philosophy, 2015) 201.

21 Moltmann, art. cit., 14.

22 Cavanaugh and Scott, op. cit., 2.

23 Kirwan, op. cit., 6.

24 Metz, op. cit., 123.

25 Lisa Sowle Cahill, "Catholic Social Teaching," The Cambridge Companion to Christian Political Theology, ed. Craig Hovey and Elizabeth Phillips (New York: Cambridge University Press, 2015) 74.

26 James K. A. Smith, Awaiting the King: Reforming Public Theology (Michigan: Baker Academic, 2017) 41, 64.

27 Stephan van Erp, "World and Sacrament: Foundations of the Political Theology of the Church," Louvain Studies 39 (2016) 102.

28 Joris Geldhof, Liturgy and Secularism: Beyond the Divide (Minnesota: Liturgical Press, 2018) 16. Italic original.

29 Ibid., 17.

30 David W. Fagerberg, "Liturgy, Signs, and Sacraments," The Oxford Handbook of Sacramental Theology, ed. Hans Boersma and Matthew Levering (Oxford: Oxford University Press, 2015) 462. The same concept is central to Sacrosanctum Concilium, Vatican II's Constitution on the Sacred Liturgy. Sacrosanctum Concilium, 10. See, Norman P. Tanner, ed., Decrees of the Ecumenical Councils: Trent to Vatican II, Vol. II (London \& Washington: Sheed and Ward \& Georgetown University Press, 1990) 823.

31 Wannenwetsch, Bernd, "Liturgy," The Blackwell Companion to Political Theology, ed. William T. Cavanaugh and Peter Scott (Malden, Oxford and Victoria: Blackwell Publishing, 2004) 76.

32 Daniel M. Bell Jr., "Postliberalism and Radical Orthodoxy," The Cambridge Companion to Christian Political Theology, ed. Craig Hovey and Elizabeth Phillips (Cambridge: Cambridge University Press, 2015) 114-115.

33 Daniel M. Bell Jr., "State and Civil Society," The Blackwell Companion to Political Theology, ed. William T. Cavanaugh and Peter Scott (Malden, Oxford and Victoria: Blackwell Publishing, 2004) 430.

34 Ibid., 430.

35 Ibid., 434.

36 Bell Jr., "Postliberalism and Radical Orthodoxy," art. cit., 115.

37 Smith, op. cit., 8.

38 Ibid., 19.

39 Ibid., 8-9.

40 Bell Jr., "State and Civil Society," art. cit., 433. Elsewhere Bell states that Radical Orthodoxy is part of this postliberal political theology. Bell Jr., "Postliberalism and Radical Orthodoxy," art. cit., 113.

41 Bell Jr., "State and Civil Society," art. cit., 433.

42 Wannenwetsch, art. cit., 76.

43 George Kalantzis and Gregory W. Lee, "Introduction," Christian Political Witness, ed. George Kalantzis and Gregory W. Lee (Illinois: IVP Academic, 2014) 11. 
44 Bell Jr., "State and Civil Society," art. cit., 434.

45 Bell Jr., "Postliberalism and Radical Orthodoxy," art. cit., 116.

46 Bell Jr., "State and Civil Society," art. cit., 435.

47 Ibid.

48 Smith, op. cit., 9.

49 Ibid.

50 Ibid., 14.

51 Vincent Lloyd, The Problem with Grace: Reconfiguring Political Theology (California: Stanford University Press, 2011) 119.

52 James K. A. Smith, Desiring the Kingdom: Worship, Worldview and Cultural Formation (Michigan: Baker Academic, 2009) 40.

53 Catherine Pickstock, "Liturgy, Art, and Politics," Modern Theology 16 (2000) 178.

54 Smith, Desiring the Kingdom, op. cit., 41.

55 Ibid., 41; Cf. 51.

56 Cf. Kalantzis and Lee, op. cit., 11. A contemporary example of the idea about the political engagement of the Church through its participation as a moral instance in public sphere can be found in the thoughts of George Weigel. George Weigel, Soul of the World: Notes on the Future of Public Catholicism (Michigan: Ethics and Public Policy Center and William B. Eerdmans Publishing Company, 1996) 67.

57 Hauerwas, "Church Matters," Christian Political Witness, ed. George Kalantzis and Gregory W. Lee (Illinois: IVP Academica) 18-19.

58 Van Erp, art. cit., 117.

59 Smith, Awaiting the King, op. cit., 160.

60 Ibid., 10.

61 Ibid., 13.

62 Ibid. Such a plea is also central to William T. Cavanaugh's political theology. Cavanaugh develops his political theology as a response to a tendency that defines the political role of the Church as merely a matter of being part of civil society. See William T. Cavanaugh, Theopolitical Imagination: Discovering the Liturgy as a Political Act in an Age of Consumerism (London and New York: Bloomsbury, 2002) 53-95.

63 Smith, Awaiting the King, op. cit., 10, 55.

64 Ibid., 10. Italic original.

65 Wannenwetsch, Bernd, Political Worship, trans. Margaret Kohl (Oxford: Oxford University Press, 2004) 17, 35.

66 Ibid., 6.

67 A fine example of this ecclesial ethics is the work of Samuel Wells and Ben Quash. See Samuel Wells and Ben Quash, Introducing Christian Ethics (Oxford: Wiley Blackwell, 2010).

68 Wannenwetsch, op. cit., 17.

69 Wannenwetsch, op. cit., 241. In their book Lord, Teach Us: Lord's Prayer and the Christian Life, Willimon and Hauerwas argue that prayer is hardly reduced to personal experience with God. When we call "Abba! Father!", for instance, we join in the cry of the whole cosmos. See William H. Willimon and Stanley Hauerwas, Lord, Teach Us: Lord's Prayer and the Christian Life (Nashville: Abingdon Press, 1996) 38.

70 Wannenwetsch, op. cit., 101. 
71 Ibid., 125-126.

72 Graham Ward, “A Christian Act: Politics and Liturgical Practices," Liturgy, Time and Politics of Redemption, ed. Randi Rashkover and C. C. Pecknold (London: SCM Press, 2006) 36.

73 Smith, Awaiting the King, op. cit., 59-60.

74 Ward, art. cit., 31.

75 Wannenwetsch, op. cit., 241.

76 Smith, Awaiting the King, op. cit., 10.

77 James K. A. Smith, Imagining the Kingdom: How Worship Works (Grand Rapids, Michigan: Baker Academic, 2013) 80.

78 Smith, Desiring the Kingdom, op. cit., 63.

79 Ibid.

80 Smith, Awaiting the King, op. cit., 148.

81 Luke Bretherton, Christianity and Contemporary Politics: The Conditions and Possibilities of Faithful Witness (Oxford: Wiley Blackwell, 2010) 144-145.

82 Smith, Imagining the Kingdom, op. cit., 109. Vincent Lloyd shares the same view as he writes, "In liturgy, action and story, practice and meaning are tied together," and therefore "Liturgy is a story enacted, though narrative and action cannot be detached." See Lloyd, op. cit., 114.

83 Willimon and Hauerwas, op. cit., 47.

84 Smith, Imagining the Kingdom, op. cit., 150.

85 Smith, Awaiting the King, op. cit., 60-61.

86 Smith, Imagining the Kingdom, op. cit., 169.

87 Smith, Awaiting the King, op. cit., 61-62.

88 Ibid., 54.

89 Bruce T. Morrill, "Time, Absence, and Otherness: Divine-Human Paradoxes Boding Liturgy and Ethics," in Sacraments: Revelation of the Humanity of God - Engaging the Fundamental Theology of Louis-Marie Chauvet, ed. Philippe Bordeyne and Bruce T. Morrill (Minnesota: Liturgical Press, 2008) 147 \& 149. In this article, Morrill brings into discussion the political theology of Johann Baptist Metz and the philosophy of religion of Edith Wyschogrod. In another work, Morrill explores the relationship between liturgy and politics by discussing the concept of 'memoria passionis' of political theologian Johann Baptist Metz and the idea of 'anamnesis' of liturgical theologian Alexander Schmemann. See Bruce T. Morrill, Anamnesis as Dangerous Memory: Political Theology and Liturgical Theology in Dialogue (Minnesota: Liturgical Press, 2000).

90 Smith, Awaiting the King, op. cit., 63.

91 Ibid.

92 Gordon W. Lathrop, Holy Things: A Liturgical Theology (Minneapolis: Fortress Press, 1993) 211-212.

93 Smith, Imagining the Kingdom, op. cit., 38.

94 Bretherton, op. cit., 145.

95 Smith, Imagining the Kingdom, op. cit., 32.

96 Jennifer M. McBride, Radical Discipleship: A Liturgical Politics of the Gospel (Minneapolis: Fortress Press, 2017) 238. 